\title{
In vivo control of perilla rust disease by oak pyroligneous liquor
}

\author{
Anil Kumar Chauhan, Sun Chul Kang ${ }^{*}$ \\ Department of Biotechnology, Daegu University, Gyeongsan, Republic of Korea; \\ *Corresponding Author: sckang@,daegu.ac.kr
}

Received 24 July 2013; revised 27 August 2013; accepted 5 September 2013

Copyright (C) 2013 Anil Kumar Chauhan, Sun Chul Kang. This is an open access article distributed under the Creative Commons Attribution License, which permits unrestricted use, distribution, and reproduction in any medium, provided the original work is properly cited.

\section{ABSTRACT}

Leaves of Perilla frutescens, commonly known as perilla are widely used in Korea, due to their medicinal properties. The rust disease of perilla interrupts its wide use every year. The present study was carried out to evaluate the control of perilla rust disease by using oak pyroligneous liquor having various biological properties. The rust disease infected perilla leaves were applied with $100 \mu$ of oak pyroligneous liquor at different concentrations such as $6.25,12.5,25$ and 50 $\mu \mathrm{g} / \mathrm{ml}$. Then the leaf samples were observed for the abortion of active rust pustules (yellow color) after 48 hours of incubation at $26^{\circ} \mathrm{C}$. Further, inhibition of rust pustules development by oak pyroligneous liquor was evaluated on the leaves of artificially induced perilla rust disease. The best abortion of rust pustules by oak pyroligneous liquor was noticed at the concentration of $50 \mu \mathrm{g} / \mathrm{ml}$, where $74.4 \%$ of the pustules were aborted. Discoloration of rust pustules was also observed in the treated leaves from yellow to white when compared with the untreated control. In addition, oak pyroligneous liquor completely inhibited the development of rust pustules in artificially induced leaves even at low concentration $(6.25 \mu \mathrm{g} / \mathrm{ml})$. The results clearly indicated that oak pyroligneous liquor is a good candidate for the management of Perilla rust disease.

Keywords: Perilla frutescens; Perilla Rust Disease; Oak Pyroligneous Liquor; Coleosporium plectranthi

\section{INTRODUCTION}

Perilla (Perilla frutescens, Lamiaceae) is an edible and medicinal plant, mainly distributed in Asian countries such as Japan, Korea and China. In general, perilla has two main chemo-varietal forms such as red and green according to the external aspects by different leaf and stem colors [1]. In Korea, it has become one of the most important crops in recent years. It is a popular leafy vegetable having significant antioxidant, anti-inflammatory, antimicrobial, antidepressive, anxiolytic, chemopreventive and strong antitumor-promoting activities [24]. Due to highly acclaimed medicinal properties of perilla leaves, protections of perilla leaf diseases are of major concern. Among the various leaf diseases, the rust disease caused by the fungus Coleosporium plectranthi is the most serious leaf disease.

The rust genus, Coleosporium consists of about 100 species worldwide [5]. Most species are heteroecious and macrocyclic and produce spermogonia and aecia on the needles of Pinus and uredinia and telia on various woody and herbaceous angiosperms [6,7]. The genus is characterized by mature teliospores in the telia dividing into four celled internal basidia with or without a sterile cell at their base [8]. Perilla rust pathogen was firstly recorded in Korea as Coleosporium perillae P. Sydow, later the name has been changed to Coleosporium plectranthi [9]. Yun et al. [10] identified that the causal agent for perilla rust disease was Coleosporium plectranthi based on morphological and spore-producing fruiting structures. A variety of fungicides with different modes of action are used for the control of leaf diseases. Though fungicides have shown some promising results in controlling the pathogen, phytotoxicity and fungicide residues are the major problems besides causing environmental pollution and human health hazards [11]. Under this scenario, the search continues for environmentally more friendly methods to control plant diseases that will contribute to the goal of sustainability in agriculture. Therefore, biocontrol methods are one of the alternative ways to control the plant diseases in place of chemical fungicides.

Oak plant belonging to the genus Quercus of the fam- 
ily Fabaceae, is a small tree or a shrub mainly present in Greece, Asia Minor, Syria and Iran. Kumar et al. [12] studied that the oak pyroligneous liquor effectively inhibited the urediniospore germination of Coleosporium plectranthi under in vitro condition. Pyrolytic oils and ligninrich fractions obtained from oak bark showed potent antifungal properties [13]. The pyroligneous liquor obtained from the stem part of oak plant has been used as sterilizing agent, antimicrobial and growth promoting agent etc. [14]. They are effective against a wide variety of wood-destroying organisms especially fungus. Based on the above knowledge, the present study was carried out to evaluate the control of perilla rust disease by using oak pyroligneous liquor prepared from stem of oak plant.

\section{MATERIALS AND METHODS}

\subsection{Collection of Perilla Leaf Samples and Oak Pyroligneous Liquor}

Fresh samples of rust disease infected and uninfected perilla leaves were collected from the agricultural fields of Daegu University, Gyeongsan, Republic of Korea in July 2012. Oak pyroligneous liquor sample (prepared from the stem part of Oak tree) was purchased from the commercial market, Gyeongsan.

\subsection{Effect of Oak Extract on Rust Infected Perilla Leaves}

The rust disease infected perilla leaves (approximately 50 - 60 rust pustules/leaf) were separately applied with $100 \mu \mathrm{l}$ of oak pyroligneous liquor at different concentrations such as $6.25,12.5,25$ and $50 \mu \mathrm{g} / \mathrm{ml}$. Then the leaf samples were incubated at $26^{\circ} \mathrm{C}$ for 48 hours in a sterile plastic, air tight jar. To provide proper humidity, 5 layers of tissue paper $\left(\mathrm{Kimtech}^{\mathrm{TM}}\right)$ supplied with sterile distilled water were kept on the bottom of the jar. After the incubation time, the active rust pustules (in yellow color) were individually counted and compared with untreated control. The activity was expressed as inhibition percentage of rust pustules abortion by the sample and was calculated using the formula:

$\%$ of abortion activity $=[$ (No. of rust pustules in control leaf - No. of pustules in treated leaf)/No. of rust pustules in control leaf] $\times 100$.

\subsection{Effect of Oak Extract on the Leaves of Artificially Induced Rust Disease}

To evaluate the inhibition potential of development of rust pustules by oak pyroligneous liquor, fresh perilla leaves were artificially infected with rust spores. For this purpose, rust spores were collected from the already infected leaves. The spore suspension of $1 \times 10^{7}$ spores $/ \mathrm{ml}$ was prepared and was applied to the fresh perilla leaves.
After one day of incubation period, different concentration of oak pyroligneous liquor $(6.25,12.5,25$ and 50 $\mu \mathrm{g} / \mathrm{ml}$ ) was applied to the leaves. Then the leaves were separately incubated at $26^{\circ} \mathrm{C}$ for 10 days in a sterile airtight plastic container, with maintaining the proper humidity by supplying the autoclaved distilled water on sterile tissue paper.

\section{RESULTS AND DISCUSSION}

Perilla frutescens L. is a leafy vegetable widely cultivated in East Asia. Initial symptoms and signs of the perilla rust disease is tiny yellowish projections on the underside of the leaves and covering the whole leaves with spore masses within 2 - 3 weeks after the initial stage of infection [10]. The active rust pustules in perilla leaves were observed individually after 48 hour of incubation time. The number of rust pustules was increased in the untreated control leaves. However, application with oakpyroligneous liquor resulted in significant decreases in the number of active rust pustules (Table 1). The percentage of rust pustules abortion by oak pyroligneous liquor is depicted in Figure 1. The abortion of rust pustules by oak pyroligneous liquor was concentration dependent manner and the abortion was ranged between 13.8 and $74.4 \%$. After the application of oak pyroligneous

Table 1. Effect of oak pyroligneous liquor on perilla rust disease infected leaves.

\begin{tabular}{cccc}
\hline \multirow{2}{*}{$\begin{array}{c}\text { Concentration } \\
\mu \mathrm{g} / \mathrm{ml}\end{array}$} & \multicolumn{2}{c}{ Number of active rust pustules } & \multirow{2}{*}{$\%$ of abortion } \\
\cline { 2 - 4 } & Before treatment & After treatment & \\
\hline Control & $61.6 \pm 1.3$ & $63.2 \pm 1.7$ & - \\
6.25 & $64.5 \pm 2.1$ & $55.6 \pm 0.8$ & 13.8 \\
12.5 & $59.7 \pm 1.7$ & $44.5 \pm 1.2$ & 25.5 \\
25 & $62.5 \pm 0.8$ & $33.5 \pm 0.9$ & 46.4 \\
50 & $58.3 \pm 1.4$ & $14.9 \pm 0.4$ & 74.4 \\
\hline
\end{tabular}

(-) symbol indicates no abortion.
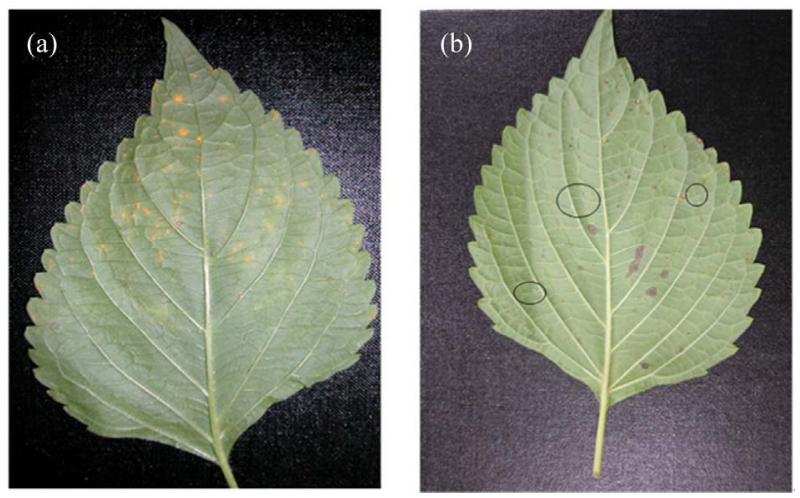

Figure 1. Effect of oak pyroligneous liquor on leaves with perilla rust infection (a) Control - untreated leaf; (b) Leaf treated with $50 \mu \mathrm{g} / \mathrm{ml}$ of oak pyroligneous liquor. The circles are showing the discoloration of yellow spore to white spore. 
liquor on the infected perilla leaves, the discoloration of the rust pustules was also observed, they turn to white as compare to fresh yellow pustules. To check the virulence of treated white rust pustules, a re-infection of spores was done in fresh uninfected perilla leaves which showed no infection even after a prolonged incubation period.

In the leaves of artificially induced rust disease, oak pyroligneous liquor completely inhibited the development of rust pustules even at the lowest concentration of $6.25 \mu \mathrm{g} / \mathrm{ml}$ (Table 2). Formation of rust pustules was observed in the untreated control leaf. Whereas, there was no rust pustules formation in the leaf treated with oak pyroligneous liquor at the concentration of $6.25 \mu \mathrm{g} /$ $\mathrm{ml}$ (Figure 2).

GC-MS analysis of oak pyroligneous liquor provided the separation of 15 different chemical components having great antimicrobial properties [12]. Among the 15 components, the major compound o-Methoxyphenol (guaiacol) in perilla plants is a well-known antimicrobial agent $[15,16]$. Al-Reza et al. [17] reported that the chemical preservatives effectively inhibited the development of rust pustules in artificially induced rust disease in perilla leaves. The present study clearly revealed that oakpyroligneous liquors are effective in controlling the peri-

Table 2. Effect of oak pyroligneous liquor on the leaves of artificially induced perilla rust disease.

\begin{tabular}{ccc}
\hline $\begin{array}{c}\text { Concentration } \\
\mathbf{\mu g} / \mathbf{m l}\end{array}$ & $\begin{array}{c}\text { Number of visible rust } \\
\text { spores pustules }\end{array}$ & \% of Spore inhibition \\
\hline Control & 82 & - \\
6.25 & 0 & 100 \\
12.5 & 0 & 100 \\
25 & 0 & 100 \\
50 & 0 & 100 \\
100 & Leaves were damage at this concentration \\
\hline
\end{tabular}

(-) symbol indicates no inhibition.
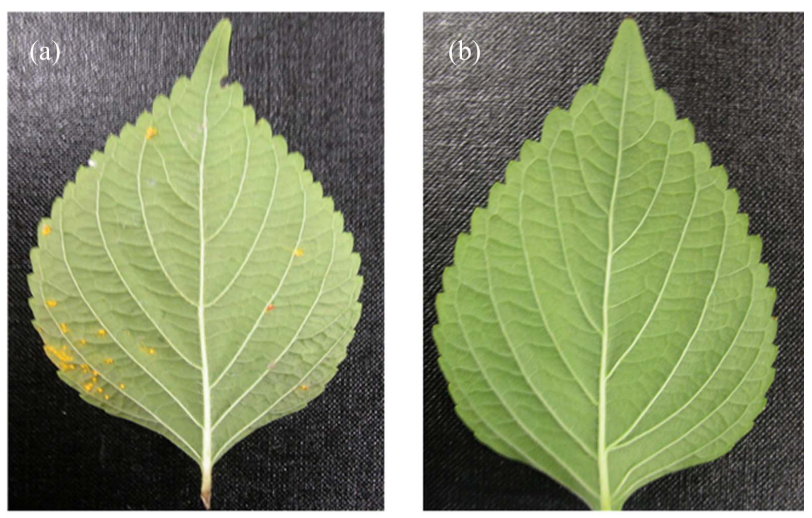

Figure 2. Effect of oak pyroligneous liquor on the leaves of artificially induced perilla rust disease. (a) Control—untreated leaf; (b) Leaf treated with $6.25 \mu \mathrm{g} / \mathrm{ml}$ of oak pyroligneous liquor showing no infection. lla rust disease. Further studies on control of perilla rust disease by oak pyroligneous liquor under field level is in progress.

\section{CONCLUSION}

The results obtained from the present study suggest that oak pyroligneous liquor has a great potential to be a natural pesticides as it can inhibit the development of rust pustules on the leaf of perilla without any toxic effect to the plant and on animal as well (toxicity test data not provided). Further researches and field trials of oak pyroligneous liquor on the fresh and growing perilla plants can reveal its more specific potential to control the disease and other beneficial aspects.

\section{REFERENCES}

[1] Saito, K. and Yamazaki, M. (2002) Biochemistry and molecular biology of the late-stage of biosynthesis of anthocyanin: Lessons from Perilla frutescens as a model plant. New Phytologist, 155, 9-23.

http://dx.doi.org/10.1046/j.1469-8137.2002.00440.x

[2] Banno, N., Akihisa, T., Tokuda, H., Yasukawa, K., Higashihara, H., Ukiya, M., Watanabe, K., Kimura, Y., Hasegawa, J. and Nishino, H. (2004) Triterpene acids from the leaves of Perilla frutescens and their anti-inflammatory and antitumor promoting effects. Bioscience, Biotechnology and Biochemistry, 68, 85-90. http://dx.doi.org/10.1271/bbb.68.85

[3] Osakabe, N., Yasuda, A., Natsume, M. and Yoshikawa, T. (2004) Rosmarinic acid inhibits epidermal inflammatory responses: Anticarcinogenic effect of Perilla frutescens extract in the murine two-stage skin model. Carcinogenesis, 25, 549-557. http://dx.doi.org/10.1093/carcin/bgh034

[4] Park, H.Y., Nam, M.H., Lee, H.S., Jun, W., Hendrich, S. and Lee, K.W. (2010) Isolation of caffeic acid from Perilla frutescens and its role in enhancing cglutamylcys-teinesynthetase activity and glutathione level. Food Chemistry, 119, 724-730.

http://dx.doi.org/10.1016/j.foodchem.2009.07.020

[5] Kirk, P.M., Cannon, P.F., Minter, D.W. and Stalpers, J.A. (2008) Dictionary of the fungi. 10th Edition, CABI International, London.

[6] Laundon, G.F. and Rainbow, A.F. (1971) Coleosporium ipomoeae. C.M.I. Descriptions of plant pathogenic fungi and bacteria. No. 282. Commonwealth Mycological Institute, Kew.

[7] Kaneko, S. (1981) The species of Coleosporium, the causes of pine needle rusts in the Japanese Archipelago. Reports of the Tottori Mycological Institute, 19, 1-159.

[8] Mims, C.W. and Richardson, E.A. (2005) Light and electron microscopy of teliospores and teliospore germination in the rust fungus Coleosporium ipomoeae. Canadian Journal of Botany, 83, 451-458. http://dx.doi.org/10.1139/b05-020

[9] Hiratsuka, N., Sato, S., Katsuya, K., Kakishima, M., Hiratsuka, Y., Kaneko, S., Ono, Y., Sato, T., Harada, Y., Hi- 
ratsuka, T. and Nakayama, K. (1992) The rust flora of Japan. Tsukuba Shuppankai, Tsukuba.

[10] Yun, H.Y., Kim, Y.H., Hong, S.G. and Lee, K.J. (2007) First description of Coleosporium plectranthi causing perilla rust in Korea. Plant pathology Journal, 23, 7-12. http://dx.doi.org/10.5423/PPJ.2007.23.1.007

[11] Goldman, G.H., Hayes, C. and Harman, G.E. (1994) Molecular and cellular biology of bio-control Trichoderma spp. Trends in Biotechnology, 12, 478-482. http://dx.doi.org/10.1016/0167-7799(94)90055-8

[12] Kumar, V., Chauhan, A.K., Baek, K.H. and Kang, S.C. (2011) Inhibitory activity of oak pyroligneous liquor against Coleosporium plectranthi, an obligate parasite responsible for the rust disease on Perilla leaf. Korean Journal of Environmental Agriculture, 30, 453-458. http://dx.doi.org/10.5338/KJEA.2011.30.4.453

[13] Mohan, D., Shi, J., Nicholas, D.D., Pittman Jr., C.U., Steele, P.H. and Cooper, J.E. (2008) Fungicidal values of bio-oils and their lignin-rich fractions obtained from wood/bark fast pyrolysis. Chemosphere, 71, 456-465. http://dx.doi.org/10.1016/j.chemosphere.2007.10.049
[14] Loo, A.Y., Jain, K. and Darah, I. (2008) Antioxidant activity of compounds isolated from the pyroligneous acid, Rhizophora apiculata. Food Chemistry, 107, 1151-1160. http://dx.doi.org/10.1016/j.foodchem.2007.09.044

[15] Yamno, Y., Sawaki, K., Ishihara, K., Miyamoto, K., Ohno, K. and Kawaguchi, M. (2002) Component of temporal changes in components of formalin guaiacol under several storage conditions. The Bulletin of Tokyo Dental College, 43, 61-67.

http://dx.doi.org/10.2209/tdcpublication.43.61

[16] Mulyono, N., Lay. B.W., Rahayu, S. and Yaprianti, I. (2012) Antibacterial activity of petung bamboo (DendrocalamusAsper) leaf extract against pathogenic Escherichia coli and their chemical identification. International Journal of Pharmaceutical \& Biological Archives, 3, 770778.

[17] Al-Reza, S.M., Hwang, C.W. and Kang, S.C. (2010) Efficacy of chemical preservatives to control Perilla rust. Korean Journal of Environmental Agriculture, 29, 417 420. http://dx.doi.org/10.5338/KJEA.2010.29.4.417 